\title{
Vibrational Analysis and Thermal Behavior of Salvia hispanica, Nigella sativa and Papaver somniferum Seeds
}

\author{
Paula Carrión-Prieto', Pablo Martín-Ramos²*, Salvador Hernández-Navarro', losody Silva-Castro', Manuela Ramos-Silva ${ }^{3}$, Jesús Martín- \\ Gil $^{1}$
}

\begin{abstract}
Paula Carrión-Prieto, ${ }^{1}$ Pablo
Martín-Ramos, ${ }^{2 *}$ Salvador

Hernández-Navarro, ${ }^{1}$ losody

Silva-Castro, ${ }^{1}$ Manuela Ramos-

Silva, ${ }^{3}$ Jesús Martín-Gil'

${ }^{1}$ Agriculture and Forestry Engineering

Department, ETSIIAA, Universidad de

Valladolid, Avenida de Madrid 44, 34004

Palencia, SPAIN.

${ }^{2}$ Department of Agricultural and Envi-

ronmental Sciences, Higher Polytechnic School of Huesca, University of Zara-

goza, Carretera de Cuarte, s/n, 22071

Huesca, SPAIN.

${ }^{3}$ CFisUC, Department of Physics, University of Coimbra, Rua Larga, P-3004-516 Coimbra, Portugal.
\end{abstract}

\section{Correspondence}

\section{Pablo Martín-Ramos}

Department of Agricultural and Environmental Sciences, Higher Polytechnic School of Huesca, University of Zaragoza, Carretera de Cuarte, s/n, 22071 Huesca, SPAIN.

Tel: +34 (974) 292668; Fax: +34 (974) 239302.

E-mail: pmr@unizar.es

\section{History}

- Submission Date: : 27-09-2016;

- Review completed: 08-11-2016;

- Accepted Date: 11-11-2016.

DOI : 10.5530/pj.2017.2.26

Article Available online

http://www.phcogj.com/v9/i2

\section{Copyright}

(C) 2017 Phcog.Net. This is an openaccess article distributed under the terms of the Creative Commons Attribution 4.0 International license.

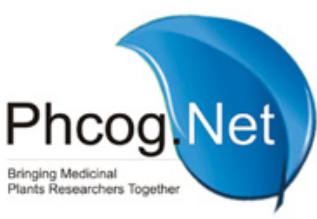

\begin{abstract}
Introduction: Salvia hispanica L., Nigella sativa L. and Papaver somniferum L. are involved in opiate-dependent behavior. It is known that the seeds of these three herbs contain high amounts of antioxidants, which are helpful in disease prevention, but further research is needed on some of their other phytochemical components (terpene alkaloids, benzoquinones and others), which are claimed to affect human opioid receptors. Methods: Seeds from the three afore mentioned plants have been studied by ATR-FTIR vibrational spectroscopy and thermo analytical techniques (TG/DTG, DTA and DSC). Results: The infrared spectrum has confirmed the presence of the ester carbonyl of terpenoid alkaloids (such as nigellamine) and the fully conjugated cyclic dione structure of quinones (e.g., thymoquinone). As regards the thermal stability of these seeds, small differences have been observed in their thermal profiles (endothermic effects at around $333^{\circ} \mathrm{C}$ for chia, $268^{\circ} \mathrm{C}$ for black cumin and $319^{\circ} \mathrm{C}$ for poppy seeds), which can be ascribed to their different content in carbohydrates. Conclusions: The functional groups of the main active constituents and the thermal behavior of these three seeds have been elucidated.
\end{abstract}

Key words: ATR-FTIR, Black cumin, Chia, Poppy, Thermal analysis.

\section{INTRODUCTION}

\section{Salvia hispanica L.}

Salvia hispanica L., commonly known as chia, is a species of flowering plant of the mint family, $L a$ miaceae, native to Central and Southern Mexico and Guatemala. ${ }^{1}$ The $16^{\text {th }}$ century Codex Mendoza provides evidence that it was cultivated by the $\mathrm{Az}$ tec in pre-Columbian times and economic historians have suggested that it may have been as important as maize as a food crop. ${ }^{2}$ Ground or whole chia seeds are still used in Paraguay, Bolivia, Argentina, Mexico, and Guatemala for nutritious drinks and as a food source. ${ }^{3}$ Today, chia is grown commercially in its native Mexico, as well as in Bolivia, Argentina, Ecuador, Guatemala and Australia. $^{2}$

Typically, chia seeds are small ovals with a diameter of approximately $1 \mathrm{~mm}$, mottled-colored with brown, gray, black and white. They are hydrophilic, absorbing up to 12 times their weight in liquid when soaked. While soaking, the seeds develop a mucilaginous coating that gives chia-based beverages a distinctive gel texture.

The composition of chia seeds has been reported by Cordain: ${ }^{4}$ fiber $\left(377 \mathrm{~g} \cdot \mathrm{kg}^{-1}\right)$, fat $\left(308 \mathrm{~g} \cdot \mathrm{kg}^{-1}\right)$, protein $\left(156 \mathrm{~g} \cdot \mathrm{kg}^{-1}\right)$ and total carbohydrates $\left(439 \mathrm{~g} \cdot \mathrm{kg}^{-1}\right)$. Calcium, potassium and magnesium were the predominant mineral elements. Saturated fats were $32 \mathrm{~g} \cdot \mathrm{kg}^{-1}$ vs. $29 \mathrm{~g} \cdot \mathrm{kg}^{-1}$ for monounsaturated fat and $233 \mathrm{~g} \cdot \mathrm{kg}^{-1}$ for polyunsaturated fat. Linolenic acid concentra- tion was three times that of linoleic and nine times that of oleic acid. The amounts of A, B1, B2, B3, B6 and $\mathrm{C}$ vitamins found in chia seeds were $37 \mathrm{IU}, 8.7$ $\mu \mathrm{g} \cdot \mathrm{g}^{-1}, 1.7 \mu \mathrm{g} \cdot \mathrm{g}^{-1}, 58 \mu \mathrm{g} \cdot \mathrm{g}^{-1}, 6.9 \mu \mathrm{g} \cdot \mathrm{g}^{-1}$ and $157 \mu \mathrm{g} \cdot \mathrm{g}^{-1}$, respectively. Among the water-soluble vitamins determined, pantothenic acid was found at $9.40 \mu \mathrm{g} \cdot \mathrm{g}^{-1}$. Myricetin was the main flavanol (with a concentration three times higher than that of kaempferol). The antioxidants in chia seeds are polyphenols (namely myricetin, quercetin and kaempferol). Total phenolics have been quantified at $47 \mathrm{mM}$ per $1,000 \mathrm{~g}$ of seeds (caffeic acid equivalents). ${ }^{5}$

\section{Nigella sativa $\mathrm{L}$.}

Nigella sativa is an annual flowering plant, native to Asia and the Middle East, which grows to $20-30 \mathrm{~cm}$ (8-12 in) tall. The flowers of this plant, which appear between June and September, have five petals about $2.5 \mathrm{~cm}$ wide, usually white but occasionally tinted with pale blue veins. They yield a seed capsule with five compartments, each of which is topped by a spike, and that open to allow seed dispersion. The seeds are small, matte-black grains with a rough surface and an oily white interior. They are triangulate, 2 $\mathrm{mm}$ in length and look similar to onion seeds.

The seeds of $N$. sativa have been traditionally prized for their healing properties. ${ }^{6-11}$ While frequently referred to amongst English-speaking cultures as Roman coriander, black sesame, black caraway and onion seed, it is known today primarily as black seed, which is at the very least an accurate description of its 
physical appearance. The earliest record of its cultivation and use come from ancient Egypt: black seed oil was found in Egyptian pharaoh Tutankhamun's tomb, dating back to approximately 3,300 years ago. Black seed is also mentioned as the curative black cumin in the Holy Bible and is described as melanthion by Hippocrates and Dioscorides and as gith by Pliny. In Arabic cultures, black seed is known as habbatul barakah, meaning 'the seed of blessing'.

Nergiz and Ötleş ${ }^{12}$ reported the following composition for Nigella seeds: crude fiber $\left(66 \mathrm{~g}^{\mathrm{kg}} \mathrm{kg}^{-1}\right)$, fat $\left(320 \mathrm{~g} \cdot \mathrm{kg}^{-1}\right)$, protein $\left(202 \mathrm{~g} \cdot \mathrm{kg}^{-1}\right)$ and total carbohydrates $\left(374 \mathrm{~g} \cdot \mathrm{kg}^{-1}\right)$. Potassium, calcium and sodium were again the predominant mineral elements. Oleic, linoleic and palmitic acids were $22 \%, 61 \%$ and $11 \%$, respectively. The amounts of $\alpha$-, $\beta$ - and $\delta$-tocopherols found were $40 \mu \mathrm{g} \cdot \mathrm{g}^{-1}, 50 \mu \mathrm{g} \cdot \mathrm{g}^{-1}$ and $250 \mu \mathrm{g} \cdot \mathrm{g}^{-1}$, respectively. B1, B2, B6 and PP vitamins concentrations were $8.31 \mu \mathrm{g} \cdot \mathrm{g}^{-1}, 0.63 \mu \mathrm{g} \cdot \mathrm{g}^{-1}, 7.9 \mu \mathrm{g} \cdot \mathrm{g}^{-1}$, and $63 \mu \mathrm{g} \cdot \mathrm{g}^{-1}$, respectively. The most important active compounds were thymoquinone (30\%-48\%), thymohydroquinone, dithymoquinone, $\mathrm{p}$ cymene (7\%-15\%), carvacrol (6\%-12\%), 4-terpineol (2\%-7\%), $t$-anethol (1\%-4\%), sesquiterpene longifolene (1\%-8\%) a-pinene and thymol. ${ }^{13}$

\section{Poppy seeds (Papaver somniferum L.)}

Poppy plant is a biennial herb of Asia Minor and Eastern Mediterranean origin, belonging to the Papaveraceae family and Papaver genus. Its scientific name is Papaver somniferum. The tiny kidney-shaped seeds from the opium poppy are less than a millimeter in length and have a pitted surface. They have been harvested from dried seed pods by various civilizations for thousands of years. Nutty and pleasant in taste, the seeds are used, whole or ground, as an ingredient in many foods, and they are pressed to obtain poppy seed oil. ${ }^{14-18}$ Their primary flavor compound is 2-pentylfuran. ${ }^{18}$

In 2006 by Nergiz and Ötles ${ }^{18}$ studied the composition of poppy seeds: fat $\left(440 \mathrm{~g} \cdot \mathrm{kg}^{-1}\right)$, protein $\left(211 \mathrm{~g} \cdot \mathrm{kg}^{-1}\right)$, moisture $\left(50 \mathrm{~g} \cdot \mathrm{kg}^{-1}\right)$, ash $\left(63 \mathrm{~g} \cdot \mathrm{kg}^{-1}\right)$, crude fiber $\left(62 \mathrm{~g} \cdot \mathrm{kg}^{-1}\right)$ and total carbohydrates $\left(236 \mathrm{~g} \cdot \mathrm{kg}^{-1}\right)$. Potassium and calcium were the predominant mineral elements. Linoleic acid was the major unsaturated fatty acid, while palmitic acid was the main saturated one. The amounts of $\alpha$-, $\beta$ - and $\delta$-tocopherols found in poppy seed were $220 \mu \mathrm{g} \cdot \mathrm{g}^{-1}, 40 \mu \mathrm{g} \cdot \mathrm{g}^{-1}$ and $20 \mu \mathrm{g} \cdot \mathrm{g}^{-1}$, respectively. Among the water-soluble vitamins determined, pantothenic acid was predominant, followed by niacin and thiamin.

\section{On the interaction of seed components and opiate receptors}

It is known that Papaver seeds contain minute traces of opiates (alkaloids as opium and codeine occur in poppy seeds, albeit in tiny quantities, as a result of insect damage or through poor harvesting practices), but it is less known that Salvia and Nigella species seeds contain terpenoids and quinones that interact with opiate receptors. Although Salvia hispanica seeds do not share with Salvia divinorum seeds the presence of salvinorin A diterpenoid (a potent non-nitrogenated agonist at the $\kappa$-opioid receptor), it has been claimed that it may alleviate opiate withdrawal symptoms. Likewise, thymoquinone from Nigella sativa acts on $\mu$ - and $\kappa$-opioid receptors. This quinone is a calcium channel blocker, and drugs in this group are frequently used to help opiate addicts overcome their addiction. ${ }^{19-21}$

In the work presented here in, a rapid and accurate method for the fast and simultaneous qualitative and quantitative characterization of natural products and their constituents, ${ }^{22}$ namely Attenuated Total Reflection-Fourier-Transform Infrared spectroscopy (ATR-FTIR), and three thermo analytical techniques (viz., thermo gravimetry (TG/DTG), differential thermal analysis (DTA) and differential scanning calorimetry (DSC)) have been used to study the chemical properties and thermal behavior of the three aforementioned seeds.

\section{MATERIALS AND METHODS}

\section{Samples}

Salvia hispanica seeds were obtained from Supreem Pharmaceuticals Mysore Pvt. Ltd. (Mysore, India). Nigella sativa seeds were obtained from Natco Foods Ltd. (Buckingham, UK). Papaver somniferum seeds were obtained from the Government Opium Factory (Neemuch, Madhya Pradesh, India).

\section{Methodology}

Seed moisture content, expressed as percentage by mass, was determined using $5 \mathrm{~g}$ of seeds by adapting AOAC method 934.06. ${ }^{23}$ A Heraeus $\mathrm{T}$ 6030 heating and drying oven (Thermo Scientific, Waltham, MA, USA) regulated at $105^{\circ} \mathrm{C}$ was used. The difference between the results of two last determinations was $0.1 \mathrm{~g}$ of moisture per $100 \mathrm{~g}$ of sample. Nutritional composition of the seeds was determined using the recommended methods of the AOAC. ${ }^{23}$ Ash content was determined by incinerating $5 \mathrm{~g}$ of oil cake at $550^{\circ} \mathrm{C}$ in a muffle furnace. Crude protein content was calculated from the nitrogen content measured by the Kjeldahl procedure with a Vapodest 20 instrument (C. Gerhardt Gmbh \& Co., Königswinter, Germany) using a 6.25 factor. An estimation of crude fiber was obtained by difference between dry weight and ash content of the residue. ${ }^{23}$ Total fat content was obtained by the Soxhlet extraction method using $n$ hexane as described by IUPAC Method 1.122. Carbohydrate content was obtained by subtracting the sum of protein, fat, ash and moisture from 100. Fatty acid methyl esters were prepared by methylation of the lipids according to IUPAC method 2.301. Gas chromatography (GC) of the methyl esters was conducted on an Agilent Technologies (Santa Clara, CA, USA) 7890A, equipped with a hydrogen flame ionization detector. For the tocopherol analysis, an Agilent Technologies 1200 Series highperformance liquid chromatograph (HPLC) was used. ${ }^{24}$ Total polyphenols were determined according to Nergiz and Ünal. ${ }^{25}$

The vibrational spectra of the materials in the $400-4000 \mathrm{~cm}^{-1}$ range were measured using a Thermo Scientific (Waltham, MA, USA) Nicolet iS50 FT-IR Spectrometer, equipped with an in-built diamond attenuated total reflection (ATR) system.

TG/DTG/DTA/DSC analyses were conducted with a Perkin-Elmer (Waltham, MA, USA) STA6000 simultaneous thermal analyser by heating the samples in a slow stream of $\mathrm{N}_{2}(20 \mathrm{~mL} / \mathrm{min})$ from room temperature up to $500^{\circ} \mathrm{C}$, with a heating rate of $20^{\circ} \mathrm{C} / \mathrm{min}$. Pyris v. 11 software was used for data analysis.

\section{RESULTS AND DISCUSSION}

\section{Chemical composition}

The analytical results for seed moisture, ash, crude fiber, total fat content, carbohydrate content fatty acids, total tocopherols and total polyphenols for the three vegetal species, summarized in Table 1, were in good agreement with the bibliography., ${ }^{4,512,18,25}$

\section{Vibrational characterization}

The ATR-FTIR spectra of the three seeds under study are depicted in Figure 1, and their main bands with their respective assignments are summarized in Table 2 . It can be observed that they are closely related, in particular those of Salvia hispanica and Nigella sativa species. The relationship with the spectra of calafate (Berberis buxifolia L. $)^{26}$ and rosehip (Rosa rubiginosa L.) ${ }^{27}$ seeds, also included in Table 2 for comparison purposes, is also very high.

The highest absorbance for the three spectra occurred at $1022 \mathrm{~cm}^{-1}$. Poppy seeds spectrum showed a main peak at $1313 \mathrm{~cm}^{-1}$ and one at $777 \mathrm{~cm}^{-1}$, 
Table 1: Comparison of the compositions of the three seeds under study.

\begin{tabular}{|c|c|c|c|}
\hline & Chia seeds & Black cumin seeds & Poppy seeds \\
\hline Moisture (\%) & 5.9 & $3.8-6.4$ & $3.5-5.9$ \\
\hline Ash (\%) & 4 & $4-5$ & $5-6$ \\
\hline Crude fiber $\left(\mathrm{gkg}^{-1}\right)$ & $237-377$ & $84-216$ & $195-272$ \\
\hline Fats $\left(\mathrm{gkg}^{-1}\right)$ & 285-344 & $320-406$ & $415-440$ \\
\hline Saturated (\%) & 10 & 15 & 10 \\
\hline Palmitic (\%) & 7 & 11 & $8.6-10$ \\
\hline Stearic (\%) & 3 & 3 & \\
\hline Monounsaturated (\%) & 8 & 23 & $5-11$ \\
\hline Oleic (\%) & 7 & 22 & $4-11$ \\
\hline Polyunsaturated (\%) & 82 & 62 & 75 \\
\hline Omega 6 - Linoleic (\%) & 20 & 61 & 45 \\
\hline Omega 3 - Linolenic (\%) & 62 & 1 & 27 \\
\hline Protein $\left(\mathrm{gkg}^{-1}\right)$ & $156-267$ & 202 & $180-235$ \\
\hline Carbohydrate $\left(\mathrm{g} \mathrm{kg}^{-1}\right)$ & $260-439$ & 374 & $236-281$ \\
\hline Tocopherols $\left(\mu \mathrm{gg}^{-1}\right)$ & 1000 & 340 & 280 \\
\hline$a\left(\mu g^{-1}\right)$ & 25 & 40 & 220 \\
\hline$\beta\left(\mu g^{-1}\right)$ & 25 & 50 & 40 \\
\hline$\gamma\left(\mu g g^{-1}\right)$ & 944 & 250 & 20 \\
\hline Total polyphenols, including flavonoids $\left(\mu \mathrm{gg}^{-1}\right)$ & 920 & 4120 & 19377 \\
\hline
\end{tabular}

Table 2: Main bands in the ATR-FTIR spectra of the three seeds under study and their assignments.

\begin{tabular}{|c|c|c|c|c|c|c|}
\hline $\begin{array}{l}\text { Chia } \\
\text { seedst }\end{array}$ & $\begin{array}{l}\text { Dry chia } \\
\text { seeds }\end{array}$ & $\begin{array}{l}\text { Black cumin } \\
\text { seeds }\end{array}$ & $\begin{array}{l}\text { Poppy } \\
\text { seeds }\end{array}$ & $\begin{array}{c}\text { Calafate } \\
\text { seeds }\end{array}$ & $\begin{array}{c}\text { Rosehip } \\
\text { seeds }\end{array}$ & Assignments \\
\hline 3294 & 3292 & 3281 & 3280 & 3290 & & $v(\mathrm{OH}), v(\mathrm{C}-\mathrm{H})$ \\
\hline 3010 & 3010 & 3009 & 3009 & 3010 & 3007 & $v(\mathrm{C}-\mathrm{H}), v(=\mathrm{CH})$ \\
\hline 2925 & 2925 & 2923 & 2924 & 2925 & 2920 & asym. $v(\mathrm{C}-\mathrm{H})$ \\
\hline 2854 & 2854 & 2853 & 2854 & 2854 & 2850 & symmetric $v(\mathrm{C}-\mathrm{H})$ from phythyl chains (tocopherols) \\
\hline 1735 & 1732 & 1744 & 1743 & 1743 & 1730 & $v(\mathrm{CO})$ ester from terpene alkaloids \\
\hline \multirow[t]{2}{*}{1627} & 1627 & 1633 & & 1637 & & $v(\mathrm{C}=\mathrm{O})$ quinoid ring $/ \delta(\mathrm{N}-\mathrm{H})$ (amide $\mathrm{I})$ \\
\hline & & & 1615 & & 1614 & $v(\mathrm{C}=\mathrm{C})$ quinoid ring \\
\hline 1548 & 1538 & 1540 & 1548 & 1539 & & phenolic C-O (tocopherols) / \\
\hline 1519 & & & & & 1521 & phenyl rings / $\delta(\mathrm{N}-\mathrm{H})$ (amide II) \\
\hline $1456 / 1434$ & 1435 & 1456 & 1456 & 1440 & 1456 & $\delta\left(\mathrm{CH}_{2}\right)$ \\
\hline 1417 & 1417 & 1416 & 1416 & 1412 & 1412 & $\omega \mathrm{CH}_{2}, \mathrm{O}-\mathrm{H}$ in plane def. \\
\hline 1373 & 1373 & 1378 & 1379 & 1379 & 1371 & $\delta\left(\mathrm{CH}_{2}\right)_{2}$ quinones \\
\hline$(1313)$ & & $(1316)$ & 1313 & & & coupled $\mathrm{C}-\mathrm{C} / \mathrm{C}=\mathrm{C}$ vibration \\
\hline 1240 & 1239 & 1239 & 1235 & 1238 & 1238 & phenolic C-O (tocopherols) / $\delta(\mathrm{N}-\mathrm{H})$ (amide III) \\
\hline 1154 & 1151 & 1143 & 1140 & 1140 & 1161 & methyl ester, $v(\mathrm{C}-\mathrm{O}-\mathrm{C})$ \\
\hline \multirow[t]{2}{*}{1098} & 1099 & & & & 1115 & starch $\mathrm{OH}$, cellulose \\
\hline & & & & 1045 & 1049 & ring resonance \\
\hline 1023 & 1019 & 1034 & 1026 & 1027 & 1012 & $\mathrm{PO}_{4}^{3-} / v(-\mathrm{C}=\mathrm{O}) /$ aromatic ring $\mathrm{C}-\mathrm{H}$ \\
\hline \multirow[t]{2}{*}{891} & 892 & 871 & 888 & 895 & 825 & \\
\hline & & 812 & 778 & & & typical of xanthene and riboflavin \\
\hline 557 & 671 & & 560 & & & $\rho\left(\mathrm{CH}_{2}\right)_{\mathrm{n}} /$ aromatic ring $\mathrm{C}-\mathrm{H}$ \\
\hline 533 & 534 & 521 & & 521 & & \\
\hline 452 & 452 & 510 & & & & \\
\hline 460 & 510 & 460 & & & & \\
\hline
\end{tabular}

$\dagger$ Common to all color varieties 
which are very weak (or do not appear) in the spectra of the other two seeds. Both peaks can be assigned to polyphenols (flavonoids), in which poppy seeds are very rich.

Phytochemical components of seeds -such as nigellamines, thymoquinone and others- that affect the human opioid receptors, could be identified: the ester carbonyl band of terpene alkaloids appeared at $1735 \mathrm{~cm}^{-1}$ and the fully conjugated cyclic dione structure of quinones led to absorbance at $1630 \mathrm{~cm}^{-1}$ and $1615 \mathrm{~cm}^{-1}$.

\section{Thermal behavior}

The TG curves of chia seeds (Figure $2 a$ ) were closely similar for the different varieties (mottled-colored with brown, gray, black and white), so only one curve is shown. A small weight loss ( $4 \%)$ was recorded up to $150^{\circ} \mathrm{C}$ (first DTG peak), mainly due to the evaporation of a fraction of free water contained in the seed powder. Upon heating up to ca. $300^{\circ} \mathrm{C}$ (second DTG peak), approximately an additional 15\% of the original weight was lost. In this stage, desorption of all free and bound water took place from the seed molecules. An abrupt pattern of mass loss was observed when seeds were further heated above $300^{\circ} \mathrm{C}$, indicating the decomposition of the polysaccharide molecules to low molecular weight volatiles. Seeds lost nearly an additional $60 \%$ weight when heated up to $500^{\circ} \mathrm{C}$, in two steps associated to two DTG peaks at ca. $350^{\circ} \mathrm{C}$ and ca. $400^{\circ} \mathrm{C}$. The behavior of the other two seeds is analogous, with DTG peaks at ca. $266^{\circ} \mathrm{C}$ and $425^{\circ} \mathrm{C}$ for black cumin seeds (Figure $2 b$ ) and at $348^{\circ} \mathrm{C}$ and $410^{\circ} \mathrm{C}$ for poppy seeds (Figure $2 c$ ).

As regards the DTA (Figure 3) and DSC curves, the three of them show several thermal effects similar to those of typical oilseed polysaccharides. A broad endothermic transition is first observed, corresponding to moisture loss (free water) from the seed powder, peaking at around $150^{\circ} \mathrm{C}\left(142^{\circ} \mathrm{C}\right.$ in DTA and $158^{\circ} \mathrm{C}$ in DSC $)$ for chia; $117^{\circ} \mathrm{C}$ for black cumin (observed in DTA); and $110^{\circ} \mathrm{C}$ for poppy seeds (both in DTA and DSC). The endothermic peaks at $333^{\circ} \mathrm{C}$ and $460^{\circ} \mathrm{C}$ for chia, at $245^{\circ} \mathrm{C}$ and $268^{\circ} \mathrm{C}$ (very weak) for black cumin seeds, and at $319^{\circ} \mathrm{C}$ and $425^{\circ} \mathrm{C}$ for poppy seeds can be attributed to pyrolysis of glycosyl units. The intermediate exothermic effect which appears at $362^{\circ} \mathrm{C}$ for chia and the end effect for poppy seeds at $439^{\circ} \mathrm{C}$ could be related to the oxidation to the volatiles generated in the preceding endothermic process.

\section{CONCLUSIONS}

It is known that poppy seeds contain traces of opiates, but it is less known that Salvia and Nigella species seeds contain terpenoids and quinones that interact with opiate receptors. In this work, the ester carbonyl of terpenoid alkaloids (e.g., nigellamine) and the fully conjugated cyclic di-

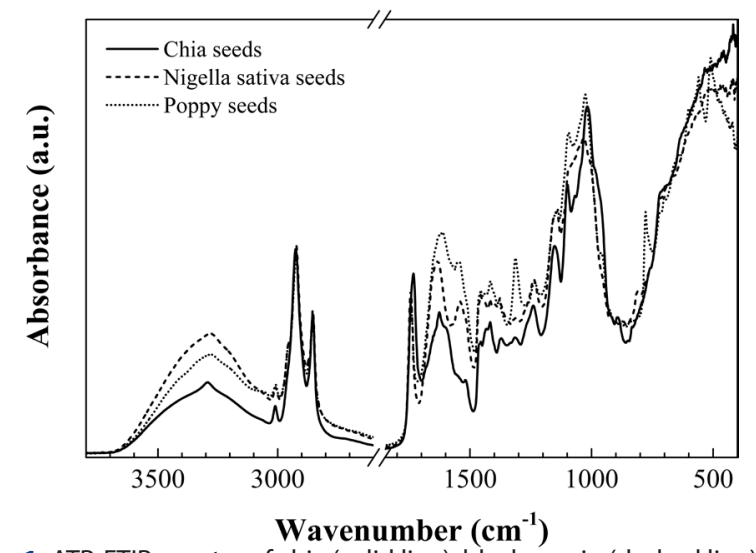

Figure 1: ATR-FTIR spectra of chia (solid line), black cumin (dashed line) and poppy (dotted line) seeds.
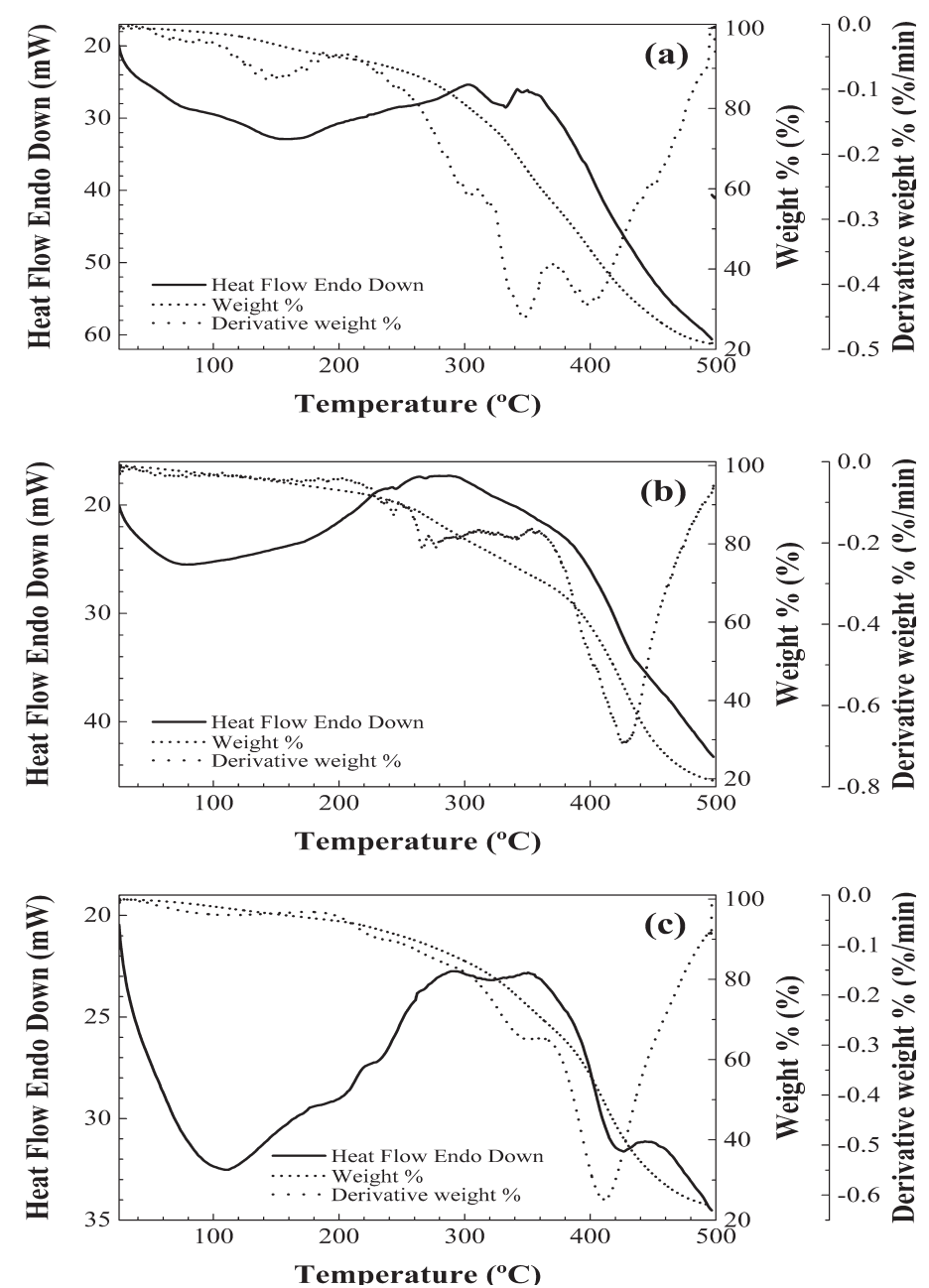

Figure 2: TG/DTG and DSC curves for chia (a), black cumin (b) and poppy (c) seeds.

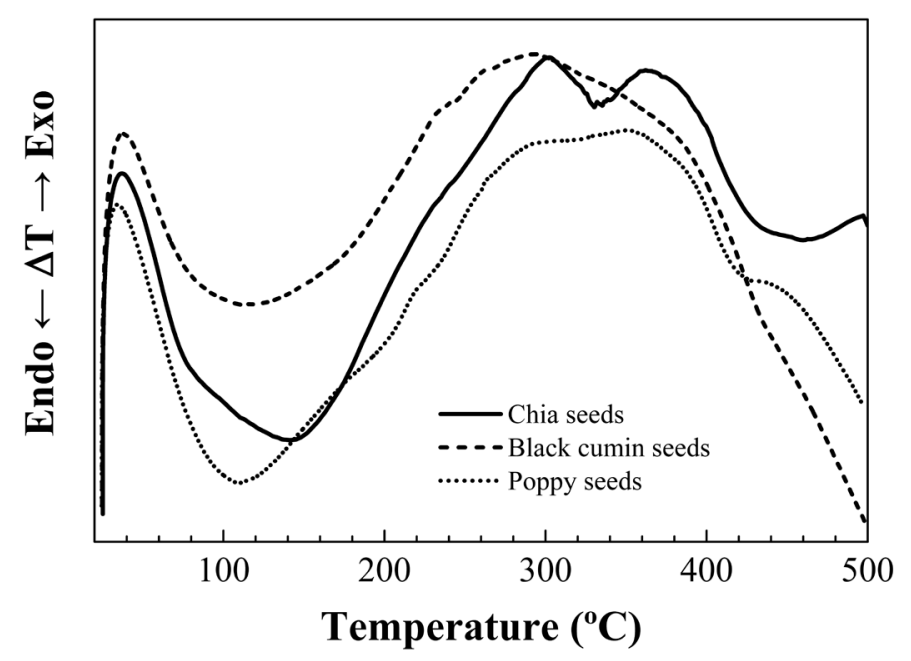

Figure 3: DTA thermograms for chia, black cumin and poppy seeds.

one structure of quinones (e.g., thymoquinone) have been identified by a rapid and precise method (ATR-FTIR spectroscopy). On the other hand, the study of the thermal profiles of the seeds by TG/DTG, DTA and DSC techniques has allowed to observe differences which could be related to the abundance of carbohydrates and fiber: pyrolysis of black cumin seeds 
takes place at temperatures $65^{\circ} \mathrm{C}$ lower than those of chia and poppy seeds, thus evincing a higher thermal stability of the latter two.

\section{ACKNOWLEDGEMENT}

Access to TAIL-UC facility funded under QREN-Mais Centro Project ICT_2009_02_012_1890 is gratefully acknowledged.

\section{CONFLICT OF INTEREST}

None

\section{ABBREVIATION USED}

ATR-FTIR: Attenuated Total Reflection-Fourier-Transform Infrared spectroscopy; DSC: differential scanning calorimetry; DTA: differential thermal analysis; DTG: derivative thermogravimetry; TG: thermogravimetry.

\section{REFERENCES}

1. U.S. National Plant Germplasm System. Salvia hispanica L. Washington DC, USA: United States Department of Agriculture; 2000 [cited 2016 Nov 3]. Available from: https://npgsweb.ars-grin.gov/gringlobal/taxonomydetail.aspx?32939.

2. Cahill JP. Ethnobotany of chia, Salvia hispanica L. (Lamiaceae). Econ Bot. 2003;57(4):604-18. http://dx.doi.org/10.1663/0013-0001 (2003)057[0604:EOCS HL]2.0.CO;2.

3. Kintzios SE. Sage: the genus Salvia. Amsterdam: Harwood Academic Publishers; 2000. p. 296

4. Cordain L. Seed fatty acid composition http://thepaleodiet.com: Cordain, Loren; 2016 [cited 2016 Nov 3]. Available from: http://thepaleodiet.com/seed-fatty-acidcomposition/.

5. Taga MS, Miller E, Pratt D. Chia seeds as a source of natural lipid antioxidants. J Am Oil Chem Soc. 1984;61(5):928-31. http://dx.doi.org/10.1007/BF02542169.

6. Worthen DR, Ghosheh OA, Crooks P. The in vitro anti-tumor activity of some crude and purified components of blackseed, Nigella sativa L. Anticancer Res. 1997;18(3A):1527-32.

7. Abdel-Fattah A-FM, Matsumoto K, Watanabe H. Antinociceptive effects of $\mathrm{Ni}$ gella sativa oil and its major component, thymoquinone, in mice. Eur J Pharmacol. 2000;400(1):89-97. http://dx.doi.org/10.1016/S0014-2999(00)00340-X.

8. Ahmad A, Husain A, Mujeeb M, Khan SA, Najmi AK, Siddique NA, et al. A review on therapeutic potential of Nigella sativa: A miracle herb. Asian Pac J Trop Biomed. 2013;3(5):337-52. http://dx.doi.org/10.1016/S2221-1691(13)60075-1.

9. Gilani A, Aziz N, Khurram I, Chaudhary K, Iqbal A. Bronchodilator, spasmolytic and calcium antagonist activities of Nigella sativa seeds (Kalonji): a traditional herbal product with multiple medicinal uses. J Pak Med Assoc. 2001;51(3):115-20.
PMid: 11381824

10. Chakravarty N. Inhibition of histamine release from mast cells by nigellone. Ann Allergy. 1993;70(3):237-42. PMid:7680846

11. Houghton PJ, Zarka R, de las Heras B, Hoult J. Fixed oil of Nigella sativa and derived thymoquinone inhibit eicosanoid generation in leukocytes and membrane lipid peroxidation. Planta Med. 1995;61(01):33-6. http://dx.doi. org/10.1055/s-2006-957994 PMid:7700988.

12. Nergiz C, Ötleş S. Chemical composition of Nigella sativa L. seeds. Food Chem. 1993;48(3):259-61. http://dx.doi.org/10.1016/0308-8146(93)90137-5

13. Desai SD, Shaik HS, Kusal KD, Haseena S. Phytochemical analysis of Nigella sativa and its antidiabetic effect. IJPSR. 2015;7(8):527-32.

14. Raghavan S. Handbook of spices, seasonings, and flavorings. $2^{\text {nd }}$ ed. Boca Raton, FL: CRC Press/Taylor \& Francis; 2007. p. 330.

15. McGee H. On food and cooking: the science and lore of the kitchen. Completely rev. And updated ed. New York: Scribner; 2004. p. 8

16. Cunningham S. Cunningham's encyclopedia of magical herbs. $1^{\text {st }}$ ed. St. Paul, Minn.: Llewellyn Publications; 1985. p. 318.

17. Hui YH. Handbook of food science, technology, and engineering. Boca Raton: Taylor \& Francis; 2006. p. 3632.

18. Nergiz C, Ötles S. The proximate composition and some minor constituents of poppy seeds. J Sci Food Agric. 1994;66(2):117-20. http://dx.doi.org/10.1002/ jsfa.2740660202.

19. Khan MA. Chemical composition and medicinal properties of Nigella sativa Linn Inflammopharmacology. 1999;7(1):15-35. http://dx.doi.org/10.1007/s10787-9990023-y PMid:17657444.

20. Akram Khan M, Afzal M. Chemical composition of Nigella sativa Linn: Part 2 Recent advances. Inflammopharmacology. 2016;24(2-3):67-79. http://dx. doi. org/10.1007/s10787-016-0262-7 PMid:27068721 PMCid:PMC4883276.

21. Sangi S, Ahmed SP, Channa MA, Ashfaq M, Mastoi SM. A new and novel treatment of opioid dependence: Nigella sativa 500 mg. J Ayub Med Coll Abbottabad. 2008;20(2):118-24.PMid:19385474

22. Huck CW. Advances of infrared spectroscopy in natural product research. Phytochem Lett. 2015;11:384-93. http://dx.doi.org/10.1016/j.phytol.2014.10.026.

23. International A. Official methods of analysis of AOAC International. 20th ed. Latimer GW, editor. Gaithersburg, MD, USA: Pharmabooks; 2016. p. 3100.

24. Carpenter AP. Determination of tocopherols in vegetable oils. J Am Oil Chem Soc. 1979;56(7):668-71. http://dx.doi.org/10.1007/BF02660070.

25. Nergiz C, Ünal K. Effect of method of extraction on the total polyphenol, 1,2-diphenol content and stability of virgin olive oil. J Sci Food Agric. 1991;56(1):79-84. http://dx.doi.org/10.1002/jsfa.2740560109

26. Martín-Ramos P, Martín-Gil J, Ramos-Sánchez MC, Hernández-Navarro S, Martín-Gil FJ. Thermal behaviour of calafate (Berberis buxifolia) seeds. Bosque. 2016;37(3):625-30.

27. Martín-Ramos P, Martín-Gil J, Ramos-Sánchez MC, Navas-Gracia LM, Hernández-Navarro S, Martín-Gil FJ. Vibrational and thermal characterization of seeds, pulp, leaves and seed oil of Rosa rubiginosa L. Boletín de la Sociedad Argentina de Botánica. 2016;51(3):429-39.

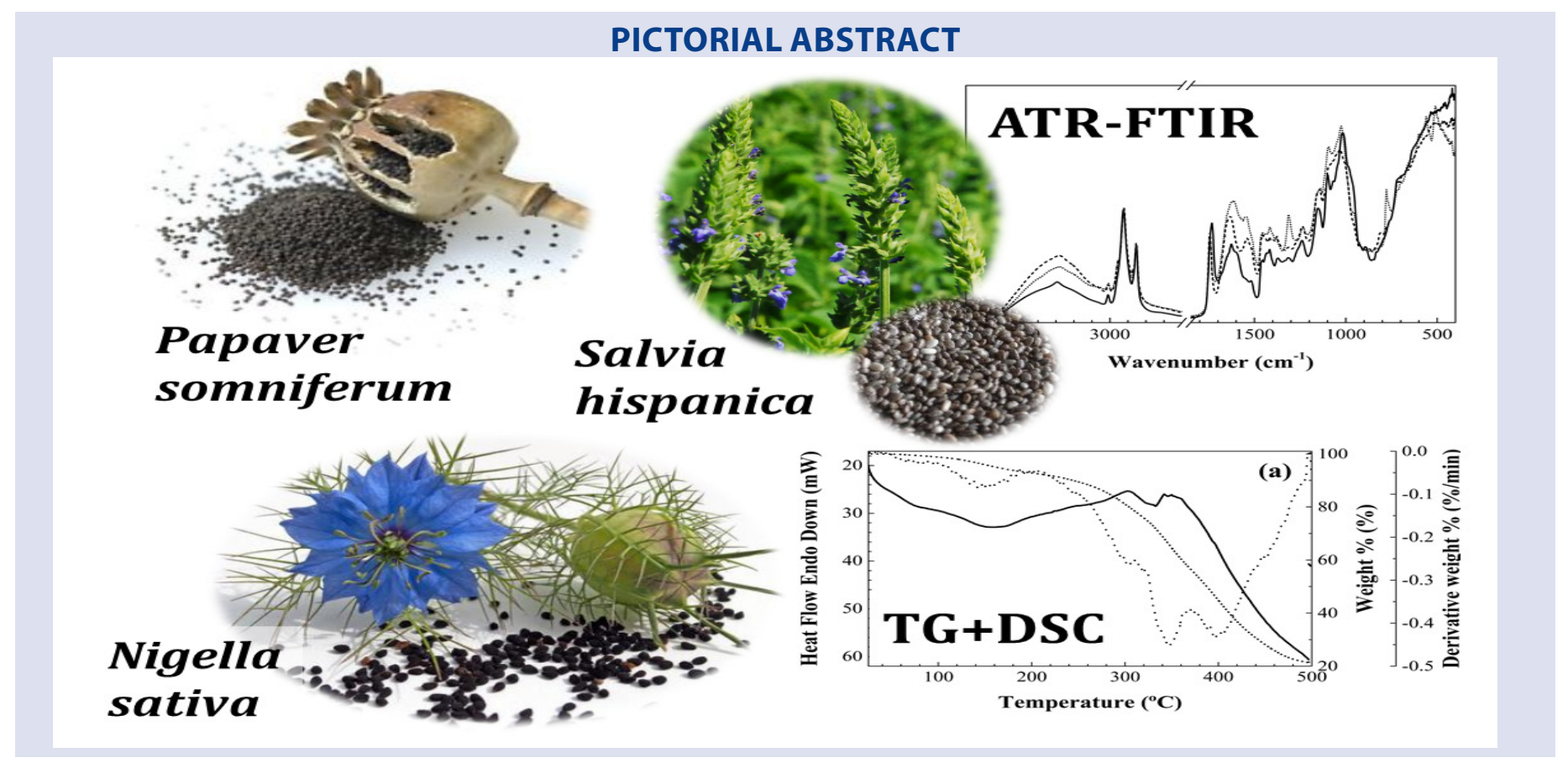



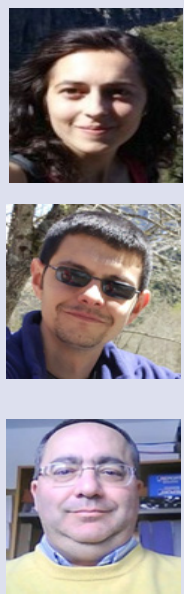

Salvador Hernández-Navarro is Professor of Agriculture and Forestry Engineering at the ETSIIAA, Universidad de Valladolid, Spain. His research interests encompass Climate Change, carbon sinks and natural products.

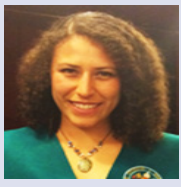

losody Silva-Castro is enrolled as a doctoral student in Agriculture and Forestry Engineering at the ETSIIAA, Universidad de Valladolid, Spain. Her PhD research focuses on natural-polymer based composite systems (with particular emphasis on chitosan) for phytosanitary applications.

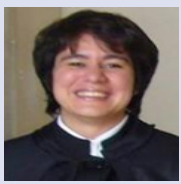

Manuela Ramos-Silva is Professor at Department of Physics, FCTUC, University of Coimbra, Portugal. She is interested in studying molecular compounds with interesting physical properties such as: molecular magnets; organic light emitting diodes, multifunctional lanthanide based materials; organic non-linear optical materials.

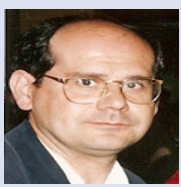

Jesús Martín-Gil is Full Professor and Chair at the Agriculture and Forestry Engineering Department, ETSIIAA, Universidad de Valladolid, Spain. As the Director of the Advanced Materials Laboratory, his research areas cover a wide spectrum of Green Chemistry applications, ranging from essential oils to photocatalysis.

Cite this Article: Carrión-Prieto P, Martín-Ramos P, Hernández-Navarro S, Silva-Castro L, Ramos-Silva M, Martín-Gil1 J. Vibrational Analysis and Thermal Behavior of Salvia hispanica, Nigella sativa and Papaver somniferum Seeds. Pharmacogn J. 2017;9(2):157-62. 